\title{
Excretory/secretory products of anisakid nematodes: biological and pathological roles
}

\author{
Foojan Mehrdana* (10) and Kurt Buchmann
}

\begin{abstract}
Parasites from the family Anisakidae are widely distributed in marine fish populations worldwide and mainly nematodes of the three genera Anisakis, Pseudoterranova and Contracaecum have attracted attention due to their pathogenicity in humans. Their life cycles include invertebrates and fish as intermediate or transport hosts and mammals or birds as final hosts. Human consumption of raw or underprocessed seafood containing third stage larvae of anisakid parasites may elicit a gastrointestinal disease (anisakidosis) and allergic responses. Excretory and secretory (ES) compounds produced by the parasites are assumed to be key players in clinical manifestation of the disease in humans, but the molecules are likely to play a general biological role in invertebrates and lower vertebrates as well. ES products have several functions during infection, e.g. penetration of host tissues and evasion of host immune responses, but are at the same time known to elicit immune responses (including antibody production) both in fish and mammals. ES proteins from anisakid nematodes, in particular Anisakis simplex, are currently applied for diagnostic purposes but recent evidence suggests that they also may have a therapeutic potential in immune-related diseases.
\end{abstract}

Keywords: Allergy, Anisakidosis, Anisakids, Excretory/secretory products

\section{Background}

Anisakid nematode larvae of the genera Anisakis, Pseudoterranova, and Contracaecum (family: Anisakidae; superfamily: Ascaridoidea; order: Ascaridida) are common parasites in a variety of marine fish species worldwide (Table 1). Different species of these parasites have been recognized, while some of them include sibling species within a particular morphospecies, e.g. Contracaecum osculatum complex [A, B, C, D, and E] [1], Anisakis simplex s.l. [A. simplex sensu stricto (s.s.), $A$. berlandi (formerly termed $A$. simplex sp. C) and A. pegreffii] [2, 3], and Pseudoterranova decipiens complex [P. decipiens (sensu stricto), P. krabbei, P. bulbosa (previously termed $P$. decipiens $\mathrm{C}$ ) and $P$. azarasi (formerly termed P. decipiens D)] [4,5]. Infection with these parasites is considered a threat to public health due to their zoonotic potential, and the presence of larvae in fish products reduces their commercial value. Free or encapsulated larvae are present within the body cavity, in the visceral organs or in the musculature of the fish host [6] whereby

\footnotetext{
*Correspondence: foojan@sund.ku.dk

Laboratory of Aquatic Pathobiology, Department of Veterinary and Animal Sciences, Faculty of Health and Medical Sciences, University of Copenhagen, 1870 Frederiksberg C, Denmark
}

larvae may accidentally be ingested by consumers. The term anisakidosis refers to the disease in humans caused by any member of the family Anisakidae, whereas anisakiasis (or anisakiosis) is specifically caused by members of the genus Anisakis, pseudoterranoviasis (or pseudoterranovosis) by the genus Pseudoterranova $[7,8]$ and contracaeciasis (or contracaecosis) is caused by members of the genus Contracaecum [9]. Recent studies have revealed that a series of allergens in Anisakis play a major role in the progression and clinical picture of the disease. These allergens are a part of a rich series of excretory and secretory (ES) worm products, which may play profound biological roles in the life cycle of these helminths. Research on anisakid ES products has so far mainly focused on Anisakis spp., in particular $A$. simplex, owing to its frequent occurrence and cause of anisakiasis. In the present work, we review the biological and pathological role of anisakid ES products with a main focus on the compounds released from the genus Anisakis.

\section{Search strategy}

A literature search was conducted in PubMed (http:// www.ncbi.nlm.nih.gov/pubmed) and ScienceDirect (http:// www.sciencedirect.com) using the terms "excretory and 


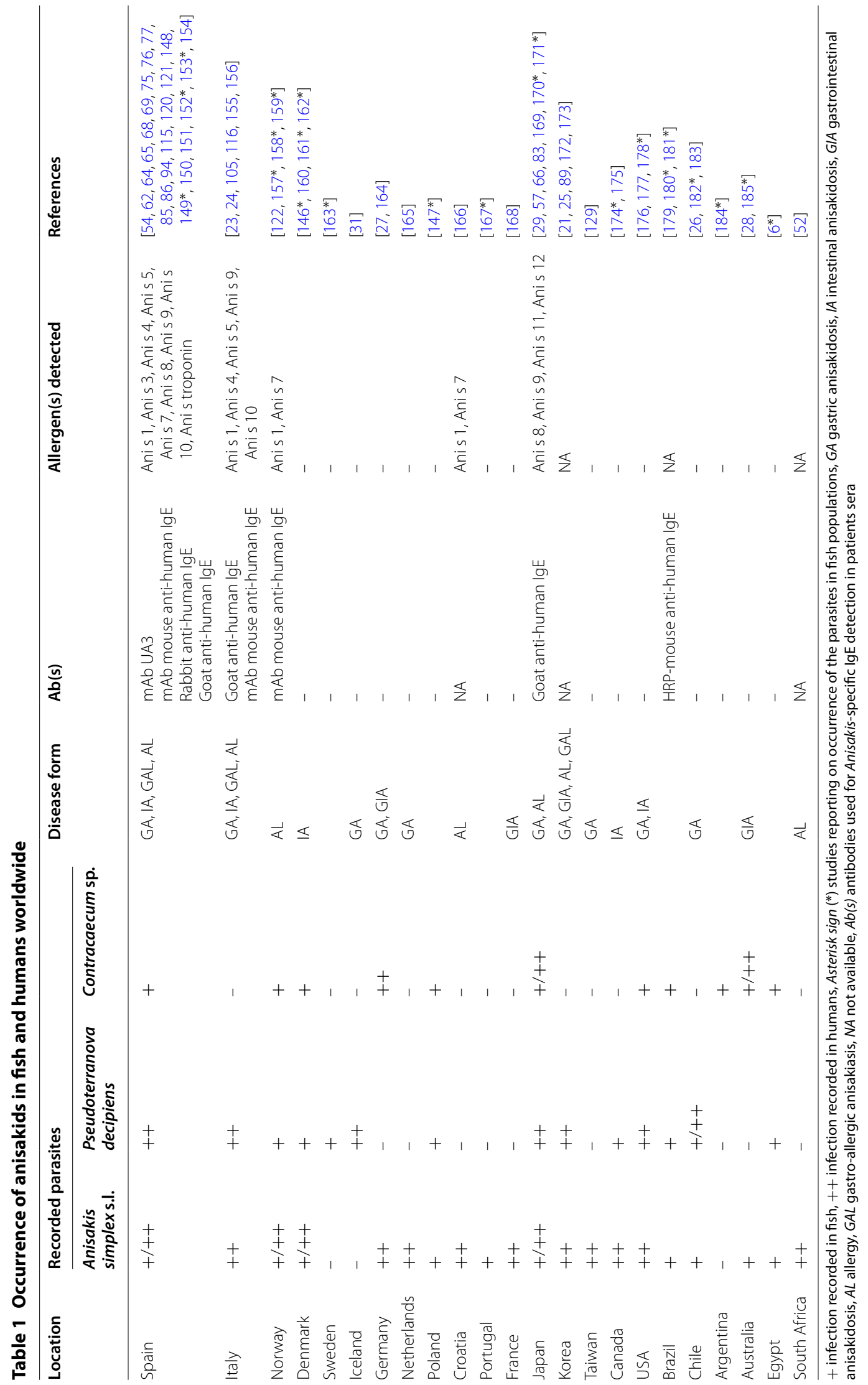


secretory products" AND "allergy" OR "anisakidosis" combined with anisakid parasites names "Anisakis" OR "Pseudoterranova" OR "Contracaecum". The title and abstract of resulted hits were evaluated and the most relevant articles were assessed in detail. Our own archives were also used as an additional source of information. The papers included in this systematic review have been published between 1960 and 2016.

\section{General biology of anisakids}

The life cycles of anisakid nematodes comprise adult worms in marine mammals, e.g. seals, sea lions, dolphins, whales $[7,10,11]$ and/or piscivorous birds [12-14] and hatched larvae which are free-living until they are ingested by an invertebrate host (e.g. a crustacean) whereafter they are transferred to a teleost transport host by predation. Humans act only as accidental hosts for anisakids. They obtain infection through consumption of raw or underprocessed seafood, but the nematodes do not reach the adult stage in humans whereby human hosts cannot transmit the infection further by releasing parasite eggs with feces. In contrast, marine mammalian hosts (pinnipeds and cetaceans) allow maturation of the anisakid worms in their gastrointestinal tract. Following copulation between adult male and female worms, parasite eggs are released by the adult female worm and leave the host with faeces to the marine environment where they develop and subsequently hatch [15]. The released free third stage larvae (L3) become ingested by the first invertebrate hosts (including crustaceans, cephalopods and polychaetes) in which they reach extra-intestinal sites such as the hemocoel, a process which must involve enzymatic activity. Following ingestion by the fish, the worm larvae penetrate the fish gut and reach internal organs such as body cavity, viscera or musculature. The fish host range depends to some extent on the anisakid species $[2,13,16]$ but their geographical distribution is also limited by the availability of the intermediate and final hosts [17]. Therefore, the presence of the parasite in a host implies the co-presence of all the required host species for completing the parasitic life cycle at the same time in the same area and indicates that ES genes encoding products needed for all steps in the life cycle are present in that particular strain of the parasite [18].

\section{Human infections}

Humans are accidental hosts of anisakid parasites, and acquire L3 through consumption of raw or inadequately processed seafood. Ingestion may cause anisakidosis, which is manifested by distinct gastrointestinal symptoms, e.g. vomiting, diarrhoea, and epigastric pain [19, 20]. Anisakis simplex s.s. (Rudolphi, 1809) is the most frequently reported causative agent for anisakiasis [8] but recently Anisakis pegreffii was reported to cause anisakiasis in the Republic of Korea [21], Croatia [22], and Italy [23, 24]. Infections caused by P. decipiens (Krabbe, 1878) [25, 26] and C. osculatum (Rudolphi, 1802) [27-29] have been reported at a lower frequency (Table 1). Infections with Pseudoterranova may in certain cases cause asymptomatic infections and come to medical attention only when worms are recovered following vomiting, coughing or defecating [30,31]. The few cases of contracaeciasis reported severe abdominal pain associated with the infection $[27,28]$.

\section{Production of ES compounds}

During all stages of the life cycle, nematodes produce and release a series of excretory and secretory molecules (ES compounds) which may be key players in parasitehost interactions including host-specificity. However, this does not necessarily mean that the composition of compounds or the individual molecules are identical at all stages [32]. It may be suggested that production of ES compounds in the third stage larvae varies (quantitatively and qualitatively) depending on the type of host (crustaceans, fish and mammals) due to the different structural and physiological conditions in these host groups. The habitat of poikilothermic organisms, such as crustaceans and fish, may reach near zero degree in certain marine areas whereas marine mammals are homoiothermic animals with body temperatures near $40{ }^{\circ} \mathrm{C}$, which challenges the temperature optima of enzymatic systems differently. Thus, the temperature-dependent production of ES compounds in Anisakis was shown by Bahlool et al. [33]. In addition, the chemical interactions (such as receptor-ligand binding) between host and parasite must differ due to conformational changes of proteins at different temperatures. A number of genes encoding central immune factors have been partly conserved throughout evolution from invertebrates via fish to mammals, but the variation is high $[34,35]$ and thereby it should be expected that host evasion mechanisms in different animal groups differ. It has also been suggested that differences among life cycles of different parasite species and even sibling species $[11,36]$ may be attributed to the relative abundance and function of these bioactive molecules influencing host specificity [37].

\section{Biochemical composition of ES products}

The ES molecules can be released from parasite organs including glands, oesophagus, ventricle, intestine and outer surfaces. In the final host, adult male and female worms mate and it is believed that during this phase chemical communication occurs between sexes which may add sex pheromones to the list of possible ES products. At all stages various enzyme activities have been 
associated with the released materials. Enzymes serving a basic metabolic role in the parasite, acid and alkaline phosphatases are found [33] and together with enzymes connected to infectivity, immune evasion and pathogenicity (proteases, nucleotidases, esterases, glycases, dismutases) they may serve roles at all life cycle stages. However, no studies have as yet been presented showing the action of ES products in invertebrate hosts and it cannot be excluded that different isotypes are expressed to different degrees in intermediate and final hosts. It is known that hydrolytic enzymes enable the worm to penetrate and migrate in fish tissues [33] and several other functions have also been suggested for secreted proteins from nematodes. For example, some anticoagulant activities are recorded from larval A. simplex ES products causing prolongation of partial thromboplastin time (PTT) which may have a key role in human anisakiasis regarding larval penetration into the gastrointestinal mucosa [38]. Moreover, a number of ES compounds from A. simplex larvae ranging from 66 to $95 \mathrm{kDa}$ may have a cytostatic inhibitory effect on lymphocyte blastogenesis [39]. Acetylcholinesterase (AChE) released by some gastrointestinal nematodes may play an important role in altering permeability of host intestinal cells to secure parasite feeding and therefore survival. This enzyme may also adversely affect coagulation and glycogenesis in the host [40]. Podolska and Nadolna [41] speculated that increased secretion of AChE from A. simplex larvae in herring should be considered an adaptive response to neurotoxic compounds released by the host. In general, nematode secretions have immunomodulatory effects interfering with host immune responses. AChE, glutathione-S-transferase (GST), and superoxide dismutase (SOD) secreted by the hookworm Necator americanus are known to suppress host inflammatory responses [42]. This is in line with secreted AChE from the filarial nematode Wuchereria bancrofti where the suppressive effect is due to degradation of acetylcholine, a neurotransmitter, which is responsible for releasing lysosomal enzymes and phagocytosis in the host [43]. AChE produced by the ruminant nematodes Ostertagia and Haemonchus has been assumed to affect host responses by controlling gastric acid secretion [40]. GST has been identified in secretions from the swimbladder nematode Anguillicoloides crassus in European eels and its function was suggested to quench reactive oxygen radicals released as part of the host innate responses toward the infection [44]. Proteolytic enzymes produced by $A$. simplex larvae are likely to target central proteins in the teleost immune system, e.g. antibodies and complement factors, and thereby enhance the parasite survival in the fish [33].
Future proteomic studies are likely to extend the list of annotated molecules in the ES molecule mixture of anisakids but it may be worthwhile to search molecules already described from a range of parasites (see the review [37]). Thus, apart from a range of enzymes and antioxidants, functional effector molecules including protease inhibitors, lectins, heat shock proteins, mucins and cytokine regulators may be detected.

\section{Immunogenicity of ES products}

Many of the A. simplex ES molecules are highly immunogenic and can provoke antibody production both in fish and mammals. Serum obtained from infected saithe (Pollachius virens) were found to react with larval A. simplex molecules in an enzyme linked immunosorbent assay (ELISA) [45], and specific antibodies from European eel (Anguilla anguilla) reacting against GST in ES isolated from $A$. crassus were detected by western blotting [44]. ES molecules in other anisakid larvae have not been studied to the same extent, but several proteins from Contracaecum species have been isolated and shown to elicit a humoral response in Antarctic teleosts [46]. Seals also produce antibodies with affinity to anisakid antigens. In a study focusing on seal serum antibody reactivity against the adult lungworm Otostrongylus circumlitus, it was found that the sera also reacted with whole body extract of other nematodes including Pseudoterranova sp. and Anisakis sp. [47]. This corresponds to the well-studied antibody production in mammals against nematode antigens, which even has been found associated with protective immunity $[48,49]$. The humoral immune reactions against ES products from $A$. simplex in accidentally infected humans have been intensely investigated. Several immunoglobulin classes may be involved, but worm specific IgE has attracted considerable interest because it is associated with disease progression and allergic responses to the parasite.

\section{Allergenicity of ES products}

Symptoms associated with anisakid nematode larvae present in human tissues may-at least in some casesbe due to allergic responses. Allergens in A simplex comprise both somatic antigens (SA) and ES molecules and several have been shown to be resistant to various freeze-, heat- and digestive processes. It is believed, based on empirical data, that allergy towards $A$. simplex must be induced by an active infection by a live worm but then subsequent exposure to allergens including ES products is sufficient to elicit an allergic response [50]. However, ingestion of larvae is not the only possibility to acquire anisakid-related disease. Occupational exposure to the parasitized fish containing anisakid allergens can elicit 
allergic reactions, e.g. bronchial hyperreactivity and dermatitis [51-53].

\section{Anisakis allergens}

Anisakis simplex has so far been described as the only anisakid parasite responsible for allergic reactions in humans. Different groups of allergenic molecules have been isolated from L3 larvae; (1) ES proteins secreted by the parasite, (2) SA of the larval organs, and (3) cuticular proteins [8]. Allergenic proteins (Ani s1 to Ani s12, Ani s 13, Ani s 14, Ani s $24 \mathrm{kDa}$, Ani s CCOS3, Ani s cytochrome B, Ani s FBPP, Ani s NADHDS4L, Ani s NARaS, Ani s PEPB, and Ani s troponin) have been described in A. simplex, of which Ani s 1, Ani s 2, Ani s 7, Ani s 12, Ani s 13, Ani s 14, and an Ani S 11-like protein (Ani s 11.0201) are identified as major allergens [54-60]. Allergens Ani s 7 and Ani s 10-12 are still uncharacterized with unknown functions [54]. A number of putative novel allergens (cyclophilin and two proteins with unknown function) have recently been characterized for the first time from $A$. simplex transcriptomes by comparing predicted amino acid sequences with homologous known allergenic proteins [61]. In general, $A$. simplex ES allergens are known to be more potent which could be a result of their higher affinity to specific IgE compared to the somatic antigens [62].

\section{Allergen persistence}

Despite the fact that anisakid larvae lose their infectivity by adequate food preparation, it should be noted that parasite allergens (SA or ES products) may be resistant to heat, freezing, and pepsin (Ani s 1, Ani s 4, Ani s 5, Ani s 8, Ani s 9, Ani s 10, Ani s 11.0201) as they preserve the antigenicity and may trigger allergic responses in sensitized persons following consumption of well-cooked or canned fish [60, 63-70].

\section{Allergen cross-reactivity}

IgE raised in patients against SA and ES antigens of $A$. simplex may cross-react with homologous antigens of other ascarid nematodes (e.g. Ascaris suum, Ascaris lumbricoides, Toxocara canis, Hysterothylacium aduncum), or arthropods (German cockroach, chironomids) [7173]. However, somatic proteins are more likely to crossreact, while ES antigens are more specific. For example, Ani s 2 (paramyosin, a somatic antigen) has been shown to have high similarity and, therefore, high degree of cross-reactivity with some dust mites, e.g. Acarus siro and Tyrophagus putrescentiae. Ani s 3 (tropomyosin), another somatic allergen, is also suggested to have the potential to cross-react with molecules from crustaceans, e.g. Homarus americanus (American lobster), and Metapenaeus ensis (greasyback shrimp), molluscs, e.g.
Perna viridis (green mussel), and Crassostrea gigas (giant Pacific oyster), and also with the insect American cockroach (Periplaneta americana) [74]. The allergen Ani s 1, an ES protein, is generally considered to have no crossreaction with other allergens, which make it a suitable candidate for diagnosis of hypersensitivity and intestinal anisakiasis [75, 76]. Using this allergen along with Ani s 4 has been shown to achieve a diagnostic sensitivity of $95 \%$ by IgE immunoblotting [77]. Further precision of diagnosis may be achieved if combined with detection of Ani s 5, another ES antigen, which also has demonstrated its utility for serodiagnosis of the Anisakis larvae sensitization [68].

\section{Allergens in other anisakids}

The allergenic potential of other anisakids, e.g. P. decipiens, molecules has not been studied to the same extent as A. simplex. A number of somatic antigens in C. osculatum larvae have been isolated with the molecular weight of 47,63 , and mainly $91 \mathrm{kDa}$ [46], but a recent study using experimental infection of mice with live Contracaecum sp. larvae did not show IgG or IgE antibody responses specific to SA or ES antigens [78]. However, the Contracaecum body structure and migratory strategy in the fish host are partly similar to those of Anisakis larvae [79] suggesting that further genomic and proteomic analysis of SA and ES molecules of Contracaecum L3 should be conducted.

\section{Pathology and ES products}

Pathological changes associated with anisakidosis may result from the direct tissue invasion by the larva into the gastric or intestinal mucosa, but immunological reactions (cellular and humoral) towards worm constituents are likely to play a major role. It has been suggested that the parasite pathogenicity may vary among closely related species and geographic strains [80-82] which may at least partly explain differential occurrence of disease. In addition, the infection dosage may be expected to influence the host reaction. In many cases of anisakidosis a single larva is responsible for infection. However, a total of 56 A. simplex larvae were recovered in a patient in Japan [83], and another human case in Spain was diagnosed infected with more than 200 A. simplex larvae accumulated in the gastric mucosa [84].

Clinical symptoms are partly connected to allergic reactions involving IgE-mediated hypersensitivity with resulting acute urticaria, angioedema, and anaphylaxis occasionally accompanied by gastroallergic anisakidosis [8, 85-89]. However, specific anti-Anisakis IgE is still detectable in patients over the years after the allergic episodes with a declining trend [90]. 
Cellular reactions with partial remodeling of tissues involving infiltration with macrophages, eosinophils, mast cells, neutrophils and lymphocytes at the penetration site are known to occur both in fish and pigs [33, 91]. Furthermore, in a recent in vitro study exposure of human fibroblast cell line HS-68 to A. pegreffii ES compounds led to elevation in reactive oxygen species (ROS) levels causing oxidative stress and also activation of kinases and subsequent inflammation, cell proliferation, inhibition of apoptosis and DNA damage [92].

In the case of invasive anisakidosis, ulcerations and hemorrhages are found in the intestinal or stomach wall. Even if worm larvae die in the human host, it should be noted that antigens released from the remains of the worm may induce inflammatory responses eliciting symptoms which cannot be differentiated from other disorders, e.g. cholecystitis, neoplasia, gastritis, peritonitis [93], appendicitis [94], eosinophilic gastroenteritis, and Crohn's disease [95].

\section{Diagnosis and ES products}

Diagnosis of anisakidosis initially relies on a detailed history of recent seafood consumption and may be confirmed by direct visualization and examination of the larvae. Removal of the worm by endoscopy/colonoscopy [96] or surgery [97] allows concurrent diagnosis and treatment of gastric/intestinal form of the disease, but non-invasive methods such as sonography and X-ray have also been proven as valuable diagnostic tools [98100]. Haematological evaluations may show leukocytosis, e.g. mild to moderate eosinophilia, and mast-cell degranulation [93, 101, 102]. Diagnosis of anisakiasis can be conducted with serologic tests which are partly based on reactions towards ES products of the worm. ELISA, IgE immunoblotting and ImmunoCAP can detect Anisakis-specific IgE reactivity to a complete extract of Anisakis L3 larvae which supports diagnosis of intestinal and allergic diseases [75, 103-105]. However, interpretation of results may not be clear-cut due to cross-reactivity of the $A$. simplex antigens with other antigens such as products from Ascaris spp., T. canis, insects (cockroaches) or crustaceans (shrimps) and care should be taken to omit false-positive serology results [106-108]. Since it has been shown that detection of specific IgG4 raised in the infected human host against $A$. simplex is likely to be more specific than specific IgE in diagnosis of gastroallergic anisakiasis [88, 109], detection of this Ig subclass is relevant to include in serological tests. Flow cytometry has also been applied as a tool for diagnosing allergy to Anisakis products activating basophils [110]. Skin prick tests (SPTs), inserting Anisakis products into the skin of the patient, may assist diagnosis of the allergic form of the disease mediated by cellular immune responses, but the test has a low specificity and high rate of false positives due to cross reactivity with other allergens from seafood and mites [111], and from A. lumbricoides [112, 113]. This frames the necessity of improving diagnostic kits based on specific Anisakis antigens, e.g. purified natural or recombinant allergens [114-116] and has accelerated immunoscreening of protein-expressing cDNA libraries [117], phage display system [118], and mass spectrometry-based proteomics [54] to identify novel allergen candidates.

It has been shown that the application of recombinant allergens of $A$. simplex, expressed in Escherichia coli or Pichia pastoris, can improve diagnostic assays by increasing specificity and avoid misdiagnosis caused by cross-reactions [115]. Measuring IgE reactivity to recombinant Ani s 1 (rAni s 1) and Ani s 7 (rAni s 7) allergens has been suggested as the most efficient serodiagnostic means for anisakiasis, when combining sensitivity and specificity. However, Ani s 1 is considered the major allergen in gastro-allergic anisakiasis, while Ani s 7 can be recognized independently of the amount of specific IgE production, i.e. in the case of chronic urticaria with lower serum specific IgE values [119, 120]. Furthermore, an internal fragment of the rAni s 7 (435Met-713Arg), known as t-Ani s 7, is shown to have the potential to improve serodiagnostic specificity [121]. In a recent survey of two groups of subjects in Norway, including recruited blood donors (BDO) and patients with total IgE levels $\geq 1000 \mathrm{kU} / \mathrm{l}$ (IGE+), the prevalence of anti-Anisakis IgE antibodies was 0.4 and $16.2 \%$ in the BDO and IGE+ groups, respectively. However, further analyses of Anisakis positive sera by ELISA against recombinant allergens rAni s 1 and rAni s 7 showed a seroprevalence of 0.0 and $0.2 \%$, respectively, and it cannot be excluded that false-positivity occurs due to crossreactivity to other allergens such as shrimp and house dust mite [122]. Gamboa et al. [123] also emphasized the value of rAni s 1 for diagnosing allergy to Anisakis both in vivo (SPT) and in vitro [specific IgE and basophil activation test (BAT)]. Both natural and recombinant Ani s 10 have also shown positive reactivity with $39 \%$ of $A n i-$ sakis-allergic patients' sera [69]. Besides high specificity, there are other advantages using recombinant allergens. For example, the yield of purified recombinant Anisakis proteins from bacterial cultures is higher compared to the yield of the natural protein from Anisakis larvae, while they show equivalent immunochemical properties $[124,125]$. Asturias et al. [126] reported a high yield of $6.6 \mathrm{mg} / \mathrm{L}$ culture of a purified recombinant tropomyosin from A. simplex (As-TPM), whereas the final yield of the purified natural $A s$-TPM was only $0.36 \mathrm{mg} / \mathrm{g}$ of Anisakis larvae, which advocates for inclusion of recombinant allergens in allergy diagnostic tests. 


\section{Treatment and ES products}

There is no standard medication available to treat anisakiasis. However, benzimidazoles such as the anthelmintic albendazole (400-800 mg daily for 6-21 days) have been suggested as a possible therapy [127-129]. It has also been shown that administration of corticosteroids like 6-methylprednisolone $(1 \mathrm{mg} / \mathrm{kg} / 24 \mathrm{~h}$ for 5 days) may be a useful option to treat the acute intestinal anisakiasis as an alternative to surgical resection [130]. Moreover, prednisolone (5 $\mathrm{mg} /$ day for 10 days) and olopatadine hydrochloride $(10 \mathrm{mg} /$ day for 6 weeks) have demonstrated promising results to resolve intestinal anisakiasis symptoms [100].

In addition, novel treatment options are likely to follow. Thus, in vitro studies on larvicidal activities of natural terpenes, e.g. geraniol, citronella essential oil, and tea tree essential oil [131, 132], Matricaria chamomilla essential oil (including $\alpha$-bisabolol) and in vivo work on administration of the aldehydic monoterpene citral and the alcoholic citronellol suggested that these compounds may be effective against infections caused by $A$. simplex and/or Contracaecum sp. [133-136]. Medical treatment leading to killing worm larvae in tissues may result in significant release of worm antigens (SA and/or ES products) which could exacerbate disease symptoms and it may be necessary to combine treatment with immune-moderating drugs such as corticosteroids.

\section{Therapeutic potential of anisakid molecules}

Ascarid nematode larvae carry genes encoding various immunoregulatory products which ensure the survival of the parasite in the host immune environment $[137,138]$ and ES products of anisakids are expected to have similar properties. In a mouse experimental model of asthma, induced by an A. suum allergen (APAS-3), it was shown that an ES protein, PAS-1, could reduce Th2 responses, inhibit cellular migration, suppress cytokine expression (IL-4, IL-5), and reduce chemokine production in bronchoalveolar lavage (BAL) fluid [139]. Similarly, PAS-1 has in a mouse model been shown to have an inhibitory effect (probably mediated by IL- 10 and TGF- $\beta$ secretion) on $E$. coli LPS (lipopolysaccharide)-induced inflammation via suppression of TNF- $\alpha$, IL-1 $\beta$ and IL-6 [140, 141]. Lung allergic inflammation in mice induced by ovalbumin (OVA) was inhibited by PAS-1 immunization mediated by stimulation of IL-10 and IFN- $\gamma$ production and subsequent suppression of cytokine and antibody reactions $[142,143]$. An anaphylactic immune response to peanut in a mouse model has also been inhibited partially by A. simplex or A. lumbricoides somatic extracts through reduction of specific IgG1 and subsequently inhibition of anaphylactic symptoms score [144]. It was also shown by Bahlool et al. [33] that Anisakis ES compounds decreased expression of genes encoding inflammatory cytokines. In addition, a recent study has demonstrated immunoregulatory effects of $A$. simplex ES antigens in a colitis zebrafish model [145]. These findings suggest that by appropriate biochemical techniques the immunoregulatory potential of anisakid ES molecules may be further characterized and exploited for prevention and/or treatment of inflammatory diseases.

\section{Conclusion and perspectives}

Increasing population of anisakid final hosts (marine mammals) and thereby their endoparasitic anisakid nematodes may lead to elevated infection levels in fish [146, 147]. This may together with the increasing trend of raw or undercooked seafood consumption explain increasing occurrence of anisakidosis and infection-induced allergies. ES products released by the anisakid nematodes have been shown to play a central role not only in the general biology of the parasite but also in human disease. Some ES products elicit allergic responses in humans but as in other helminths, other ES products may modify host immunity and suppress immune responses which open alternative usage of anisakid parasite products as therapeutics. In this review, we have focused on A. simplex allergens and the associated allergy, since our current knowledge is mainly limited to this species. The immunomodulatory activities of other relevant anisakids, particularly P. decipiens and C. osculatum, are still inadequately described and further investigations using in vitro and in vivo techniques are necessary to identify the allergenic or immunosuppressive properties of anisakid-originated components and elucidate the mechanisms involved in immunoregulations.

\section{Abbreviations \\ AChE: acetylcholinesterase; As-TPM: Anisakis simplex tropomyosin; BAL: bronchoalveolar lavage; BAT: basophil activation test; BDO: blood donors; ELISA: enzyme linked immunosorbent assay; ES: excretory and secretory; GST: glutathione-S-transferase; L3: third stage larvae; LPS: lipopolysaccharide; OVA: ovalbumin; PTT: partial thromboplastin time; rAni s 1: recombinant Ani s 1; ROS: reactive oxygen species; SA: somatic antigens; SOD: superoxide dismutase; SPT: skin prick test.}

\section{Authors' contributions}

FM drafted the manuscript. KB shared his valuable comments and finalized the manuscript structure and contents. Both authors read and approved the final manuscript.

\section{Authors' information}

$\mathrm{KB}$ is a professor in fish pathobiology investigating infectious diseases in fish with a particular focus on parasitic infections and fish-parasite interactions. FM is a Ph.D. candidate investigating zoonotic parasites in fish for the last 6 years and is the author of six original publications and a review in this field together with $\mathrm{KB}$.

\section{Acknowledgements}

This study was supported by the European Union's Horizon 2020 research and innovation programme through the Grant Agreement No. 634429

(ParaFishControl). 


\section{Competing interests}

Both authors declare that they have no competing interests.

\section{Funding}

This study has received funding from the European Union's Horizon 2020 research and innovation programme under Grant Agreement No. 634429 (ParaFishControl). This output reflects only the authors' view and the European Union cannot be held responsible for any use that may be made of the information contained herein.

\section{Publisher's Note}

Springer Nature remains neutral with regard to jurisdictional claims in published maps and institutional affiliations.

Received: 29 December 2016 Accepted: 14 June 2017

Published online: 23 June 2017

\section{References}

1. Orecchia P, Mattiucci S, D'Amelio S, Paggi L, Plötz J, Cianchi R, Nascetti G, Arduino P, Bullini L. Two new members in the Contracaecum osculatum complex (Nematoda, Ascaridoidea) from the Antarctic. Int J Parasitol. 1994;24:367-77.

2. Mattiucci S, Nascetti G, Clanchi R, Paggi L, Arduino P, Margolis L, Brattey J, Webb S, D’Amelio S, Orecchia P, Bullini L. Genetic and ecological data on the Anisakis simplex complex, with evidence for a new species (Nematoda, Ascaridoidea, Anisakidae). J Parasitol. 1997;83:401-16.

3. Mattiucci S, Cipriani P, Webb SC, Paoletti M, Marcer F, Bellisario B, Gibson DI, Nascetti G. Genetic and morphological approaches distinguish the three sibling species of the Anisakis simplex species complex, with a species designation as Anisakis berlandi n. sp. for A. simplex sp. C (Nematoda: Anisakidae). J Parasitol. 2014;100:199-214.

4. Mattiucci S, Paggi L, Nascetti G, Ishikura H, Kikuchi K, Sato N, Cianchi R, Bullini L. Allozyme and morphological identification of Anisakis, Contracaecum and Pseudoterranova from Japanese waters (Nematoda, Ascaridoidea). Syst Parasitol. 1998;40:81-92.

5. Paggi L, Mattiucci S, Gibson DI, Berland B, Nascetti G, Cianchi R, Bullini L. Pseudoterranova decipiens species A and B (Nematoda, Ascaridoidea): nomenclatural designation, morphological diagnostic characters and genetic markers. Syst Parasitol. 2000;45:185-97.

6. El-Asely AM, El Madawy RS, El Tanany MA, Afify GS. Prevalence and molecular characterization of anisakidosis in both European (Merluccius merluccius) and lizard head (Saurida undosquamis) hakes. GSTF J Vet. 2015;1(2). doi:10.7603/s40871-014-0001-8.

7. Margolis L. Public health aspects of "codworm" infection: a review. J Fish Res Board Can. 1977;34:887-98.

8. Audicana MT, Kennedy MW. Anisakis simplex: from obscure infectious worm to inducer of immune hypersensitivity. Clin Microbiol Rev. 2008:21:360-79.

9. Buchmann K, Mehrdana F. Effects of anisakid nematodes Anisakis simplex (s.I.), Pseudoterranova decipiens (s.I.) and Contracaecum osculatum (s.l.) on fish and consumer health. FAWPAR. 2016;4:13-22.

10. Ishikura H, Kikuchi K, Nagasawa K, Ooiwa T, Takamiya H, Sato N, Sugane K. Anisakidae and anisakidosis. In: Sun T, editor. Progress in clinical parasitology, vol. 3. New york: Springer; 1993. p. 43-102.

11. Skrzypczak M, Rokicki J, Pawliczka I, Najda K, Dzido J. Anisakids of seals found on the Southern coast of Baltic Sea. Acta Parasitol. 2014;59:165-72.

12. Barus V, Sergeeva TP, Sonin MD, Ryzhikov KM. Nematoda. In: Rysavy B, Ryzhikov KM, editors. Helminths of fish-eating birds of the palearctic region. Moscow: USSR Academy of Sciences; 1978.

13. Anderson RC. Nematode parasites of vertebrates: their development and transmission, Chapter 5: order Ascaridida. Wallingford, Oxfordshire, England: $\mathrm{CABI} ;$ 2000. p. 270-88.

14. Sanmartín ML, Cordeiro JA, Alvarez MF, Leiro J. Helminth fauna of the yellow-legged gull Larus cachinnans in Galicia, Northwest Spain. J Helminthol. 2005;79:361-71.
15. Køie M, Fagerholm HP. The life cycle of Contracaecum osculatum (Rudolphi, 1802) sensu stricto (Nematoda, Ascaridoidea, Anisakidae) in view of experimental infections. Parasitol Res. 1995;81:481-9.

16. Paggi L, Nascetti G, Cianchi R, Orecchia P, Mattiucci M, D'Amelio S, Berland B, Brattey J, Smith JW, Bullini L. Genetic evidence for three species within Pseudoterranova decipiens (Nematoda, Ascaridida, Ascaridoidea) in the North Atlantic and Norwegian and Barents Seas. Int J Parasitol. 1991;21:195-212.

17. Mattiucci S, Nascetti G. Advances and trends in the molecular systematics of anisakid nematodes, with implications for their evolutionary ecology and host-parasite co-evolutionary process. Adv Parasitol. 2008;66:47-148.

18. Culurgioni J, Figus V, Cabiddu S, De Murtas R, Cau A, Sabatini A. Larval helminth parasites of fishes and shellfishes from Santa Gilla lagoon (Sardinia, Western Mediterranean), and their use as bioecological indicators. Estuaries Coasts. 2015;38:1505-19.

19. Chai YL, Murrel KD, Lymbery AJ. Fish-born parasitic zoonoses: status and issues. Int J Parasitol. 2005;35:1233-54.

20. Dorny P, Praet N, Deckers N, Gabriel S. Emerging food-borne parasites. Vet Parasitol. 2009;163:196-206.

21. Lim H, Jung BK, Cho J, Yooyen T, Shin EH, Chai JY. Molecular diagnosis of cause of anisakiasis in humans, South Korea. Emerg Infect Dis. 2015;21:342-4

22. Mladineo I, Popović M, Drmić-Hofman I, Poljak V. A case report of Anisakis pegreffii (Nematoda, Anisakidae) identified from archival paraffin sections of a Croatian patient. BMC Infect Dis. 2016;16:42.

23. Fumarola L, Monno R, lerardi E, Rizzo G, Giannelli G, Lalle M, Pozio E. Anisakis pegreffi etiological agent of gastric infections in two Italian women. Foodborne Pathog Dis. 2009;6:1157-9.

24. Mattiucci S, Paoletti M, Borrini F, Palumbo M, Palmieri RM, Gomes V, Casati A, Nascetti G. First molecular identification of the zoonotic parasite Anisakis pegreffii (Nematoda: Anisakidae) in a paraffin-embedded granuloma taken from a case of human intestinal anisakiasis in Italy. BMC Infect Dis. 2011;11:82.

25. Yu JR, Seo M, Kim YW, Oh MH, Sohn WM. A human case of gastric infection by Pseudoterranova decipiens larva. Korean J Parasitol. 2001;39:193-6.

26. Torres P, Jercic MI, Weitz JC, Dobrew EK, Mercado RA. Human pseudoterranovosis, an emerging infection in Chile. J Parasitol. 2007;93:440-3.

27. Schaum E, Müller W. Heterocheilidiasis (case report). DMW. 1967;92:2230-3.

28. Shamsi S, Butcher AR. First report of human anisakidosis in Australia. MJA. 2011;194:199-200.

29. Nagasawa K. The biology of Contracaecum osculatum sensu lato and C. osculatum A (Nematoda: Anisakidae) in Japanese waters: a review. Biosph Sci. 2012;51:61-9.

30. McCarthy J, Moore TA. Emerging helminth zoonoses. Int J Parasitol. 2000;30:1351-60.

31. Skirnisson K. Pseudoterranova decipiens (Nematoda, Anisakidae) larvae reported from humans in Iceland after consumption of insufficiently cooked fish. Laeknabladid. 2006;92:21-5 (in Icelandic)

32. Kim JS, Kim KH, Cho S, Park HY, Cho SW, Kim YT, Joo KH, Lee JS. Immunochemical and biological analysis of allergenicity with excretorysecretory products of Anisakis simplex third stage larva. Int Arch Allergy Immunol. 2005;136:320-8.

33. Bahlool QZM, Skovgaard A, Kania PW, Buchmann K. Effects of excretory/ secretory proteins from Anisakis simplex (Nematoda) on immune gene expression in rainbow trout (Oncorhynchus mykiss). Fish Shellfish Immunol. 2013;35:734-9.

34. Buchmann K. Fish immune responses against endoparasitic nematodes_experimental models. J Fish Dis. 2012;35:623-35.

35. Buchmann K. Evolution of innate immunity: clues from invertebrates via fish to mammals. Front Immunol. 2014;5:459.

36. Kuhn T, Hailer F, Palm HW, Klimpel S. Global assessment of molecularly identified Anisakis Dujardin, 1845 (Nematoda: Anisakidae) in their teleost intermediate hosts. Folia Parasitol. 2013;60:123-34.

37. Hewitson JP, Grainger JR, Maizels RM. Helminth immunoregulation: the role of parasite secreted proteins in modulating host immunity. Mol Biochem Parasitol. 2009;167:1-11. 
38. Perteguer MJ, Raposo R, Cuellar C. In vitro study on the effect of larval excretory/secretory products and crude extracts from Anisakis simplex on blood coagulation. Int J Parasitol. 1996;26:105-8.

39. Raybourne R, Deardorff TL, Bier JW. Anisakis simplex: larval excretory secretory protein production and cytostatic action in mammalian cell cultures. Exp Parasitol. 1986;62:92-7.

40. Lee DL. Why do some nematode parasites of the alimentary tract secrete acetylcholinesterase? Int J Parasitol. 1996;26:499-508.

41. Podolska M, Nadolna K. Acetylcholinesterase secreted by Anisakis simplex larvae (Nematoda: Anisakidae) parasitizing herring, Clupea harengus: an inverse relationship of enzyme activity in the host-parasite system. Parasitol Res. 2014;113:2231-8.

42. Pritchard DI. The survival strategies of hookworms. Parasitol Today. 1995;11:255-9.

43. Bhattacharya C, Singh RN, Misra S, Rathaur S. Diethylcarbamazine: effect on lysosomal enzymes and acetylcholine in Wuchereria bancrofti infection. Trop Med Int Health. 1997;2:686-90.

44. Nielsen ME, Buchmann K. Glutathione-s-transferase is an important antigen in the eel nematode Anguillicola crassus. J Helminthol. 1997;71:319-24.

45. Priebe K, Huber C, Märtlbauer E, Terplan G. Detection of antibodies against the larva of Anisakis simplex in the pollock Pollachius virens using ELISA. Zentralbl Veterinarmed B. 1991;38:209-14.

46. Coscia MR, Oreste U. Presence of antibodies specific for proteins of Contracaecum osculatum (Rudolphi, 1908) in plasma of several Antarctic teleosts. Fish Shellfish Immunol. 1998;8:295-302.

47. Elson-Riggins JG, Riggins SA, Gulland FM, Platzer EG. Immunoglobulin responses of northern elephant and Pacific harbor seals naturally infected with Otostrongylus circumlitus. J Wildl Dis. 2004;40:466-75.

48. Dopheide TA, Tachedjian M, Phillips C, Frenkel MJ, Wagland BM, Ward CW. Molecular characterisation of a protective, 11-kDa excretory-secretory protein from the parasitic stages of Trichostrongylus colubriformis. Mol Biochem Parasitol. 1991:45:101-7.

49. McKeand JB, Knox DP, Duncan JL, Kennedy MW. Protective immunisation of guinea pigs against Dictyocaulus viviparus using excretory/secretory products of adult parasites. Int J Parasitol. 1995;25:95-104.

50. Alonso-Gómez A, Moreno-Ancillo A, López-Serrano MC, Suarez-deParga JM, Daschner A, Caballero MT, Barranco P, Cabañas R. Anisakis simplex only provokes allergic symptoms when the worm parasitises the gastrointestinal tract. Parasitol Res. 2004;93:378-84.

51. Purello-D'Ambrosio F, Pastorello E, Gangemi S, Lombardo G, Ricciardi L, Fogliani O, Merendino RA. Incidence of sensitivity to Anisakis simplex in a risk population of fisherman/fishmongers. Ann Allergy Asthma Immunol. 2000;84:439-44

52. Nieuwenhuizen N, Lopata AL, Jeebhay MF, Herbert DR, Robins TG, Brombacher F. Exposure to the fish parasite Anisakis causes allergic airway hyperreactivity and dermatitis. J Allergy Clin Immunol. 2006:117:1098-105.

53. Ventura MT, Tummolo RA, Di Leo E, D’Ersasmo M, Arsieni A. Immediate and cell-mediated reactions in parasitic infections by Anisakis simplex. J Investig Allergol Clin Immunol. 2008;18:253-9.

54. Fæste CK, Jonscher KR, Dooper MMWB, Egge-Jacobsen W, Moen A, Daschner A, Egaas E, Christians U. Characterisation of potential novel allergens in the fish parasite Anisakis simplex. EuPA Open Proteom. 2014:4:140-55.

55. Pérez-Pérez J, Fernandez-Caldas E, Marañón F, Sastre J, Bernal ML, Rodríguez J, Bedate CA. Molecular cloning of paramyosin, a new allergen of Anisakis simplex. Int Arch Allergy Immunol. 2000;123:120-9.

56. Anadón AM, Romarís F, Escalante M, Rodríguez E, Gárate T, Cuéllar C, Ubeira FM. The Anisakis simplex Ani s 7 major allergen as an indicator of true Anisakis infections. Clin Exp Immunol. 2009;156:471-8.

57. Kobayashi Y, Ohsaki K, Ikeda K, Kakemoto S, Ishizaki S, Shimakura K, Nagashima Y, Shiomi K. Identification of novel three allergens from Anisakis simplex by chemiluminescent immunoscreening of an expression cDNA library. Parasitol Int. 2011;60:144-50.

58. González-Fernández J, Daschner A, Nieuwenhuizen NE, Lopata AL, Frutos CD, Valls A, Cuéllar C. Haemoglobin, a new major allergen of Anisakis simplex. Int J Parasitol. 2015;45:399-407.

59. Kobayashi Y, Kakemoto S, Shimakura K, Shiomi K. Molecular cloning and expression of a new major allergen, Ani s 14, from Anisakis simplex. Shokuhin Eiseigaku Zasshi. 2015;56:194-9.
60. Carballeda-Sangiao N, Rodríguez-Mahillo Al, Careche M, Navas A, Caballero T, Dominguez-Ortega J, Jurado-Palomo J, González-Muñoz M. Ani s 11-like protein is a pepsin- and heat-resistant major allergen of Anisakis spp. and a valuable tool for Anisakis allergy component-resolved diagnosis. Int Arch Allergy Immunol. 2016;169:108-12.

61. Baird FJ, Su X, Aibinu I, Nolan MJ, Sugiyama H, Otranto D, Lopata AL, Cantacessi $C$. The Anisakis transcriptome provides a resource for fundamental and applied studies on allergy-causing parasites. PLoS Negl Trop Dis. 2016;10:e0004845.

62. Baeza ML, Rodríguez A, Matheu V, Rubio M, Tornero P, de Barrio M, Herrero T, Santaolalla M, Zubeldia JM. Characterization of allergens secreted by Anisakis simplex parasite: clinical relevance in comparison with somatic allergens. Clin Exp Allergy. 2004;34:296-302.

63. Audicana L, Audicana MT, de Corres LF, Kennedy MW. Cooking and freezing may not protect against allergic reactions to ingested Anisakis simplex antigens in humans. Vet Rec. 1997;140:235.

64. Caballero ML, Moneo I. Several allergens from Anisakis simplex are highly resistant to heat and pepsin treatments. Parasitol Res. 2004;93:248-51.

65. Moneo I, Caballero ML, Gónzalez-Muñoz M, Rodriguez-Mahillo Al, Rodriguez-Perez R, Silva A. Isolation of a heat-resistant allergen from the fish parasite Anisakis simplex. Parasitol Res. 2005;96:285-9.

66. Kobayashi Y, Shimakura K, Ishizaki S, Nagashima Y, Shiomi K. Purification and CDNA cloning of a new heat stable allergen from Anisakis simplex. Mol Biochem Parasitol. 2007;155:138-45.

67. Rodriguez-Perez R, Moneo I, Rodriguez-Mahillo A, Caballero ML. Cloning and expression of Ani s 9, a new Anisakis simplex allergen. Mol Biochem Parasitol. 2008;159:92-7.

68. Caballero ML, Moneo I, Gómez-Aguado F, Corcuera MT, Casado I, Rodríguez-Pérez R. Isolation of Ani s 5, an excretory-secretory and highly heat-resistant allergen useful for the diagnosis of Anisakis larvae sensitization. Parasitol Res. 2008;103:1231-3.

69. Caballero ML, Umpierrez A, Moneo I, Rodriguez-Perez R. Ani s 10, a new Anisakis simplex allergen: cloning and heterologous expression. Parasitol Int. 2011;60:209-12.

70. Carballeda-Sangiao N, Olivares F, Rodriguez-Mahillo Al, Careche M, Tejada M, Moneo I, González-Muñoz M. Identification of autoclaveresistant Anisakis simplex allergens. J Food Prot. 2014;77:605-9.

71. Pascual CY, Crespo JF, San Martin S, Ornia N, Ortega N, Caballero T, Muñoz-Pereira M, Martin-Esteban M. Cross-reactivity between IgEbinding proteins from Anisakis, German cockroach, and chironomids. Allergy. 1997;52:514-20.

72. Fernández-Caldas E, Quirce S, Marañón F, Diez Gómez ML, Gijón Botella H, López Román R. Allergenic cross-reactivity between third stage larvae of Hysterothylacium aduncum and Anisakis simplex. J Allergy Clin Immunol. 1998;101:554-5.

73. Lozano MJ, Martín HL, Díaz SV, Mañas Al, Valero LA, Campos BM. Crossreactivity between antigens of Anisakis simplex s.l. and other ascarid nematodes. Parasite. 2004;11:219-23.

74. Guarneri F, Guarneri C, Benvenga S. Cross-reactivity of Anisakis simplex: possible role of Ani s 2 and Ani s 3. Int J Dermatol. 2007;46:146-50.

75. Caballero ML, Moneo I. Specific IgE determination to Ani s 1, a major allergen from Anisakis simplex, is a useful tool for diagnosis. Ann Allergy Asthma Immunol. 2002:89:74-7.

76. Moneo I, Caballero ML, Gómez F, Ortega E, Alonso MJ. Isolation and characterization of a major allergen from the fish parasite Anisakis simplex. J Allergy Clin Immunol. 2000;106:177-81.

77. Moneo I, Caballero ML, Rodriguez-Perez R, Rodriguez-Mahillo Al, Gonzalez-Muñoz M. Sensitization to the fish parasite Anisakis simplex: clinical and laboratory aspects. Parasitol Res. 2007;101:1051-5.

78. Vericimo MA, Figueiredo I Jr, Teixeira GAPB, São Clemente SC. Experimental anisakid infections in mice. J Helminthol. 2015;89:620-4.

79. Laffon-Leal SM, Vidal-Martínez VM, Arjona-Torres G. 'Cebiche'-a potential source of human anisakiasis in Mexico? J Helminthol. 2000;74:151-4.

80. Desowitz RS. Human and experimental anisakiasis in the United States. Hokkaido Igaku Zasshi. 1986;61:358-71.

81. Suzuki J, Murata R, Hosaka M, Araki J. Risk factors for human Anisakis infection and association between the geographic origins of Scomber japonicus and anisakid nematodes. Int J Food Microbiol. 2010;137:88-93. 
82. Klimpel S, Palm HW. Anisakid nematode (Ascaridoidea) life cycles and distribution: Increasing zoonotic potential in the time of climate change? In: Mehlhorn H, editor. Progress in parasitology, parasitology research monographs 2, Chapter 11. 2011. p. 201-22.

83. Kagei $\mathrm{N}$, Isogaki $\mathrm{H}$. A case of abdominal syndrome caused by the presence of a large number of Anisakis larvae. Int J Parasitol. 1992;22:251-3.

84. Jurado-Palomo J, López-Serrano MC, Moneo I. Multiple acute parasitization by Anisakis simplex. J Investig Allergol Clin Immunol. 2010;20:437-41.

85. Moreno-Ancillo A, Caballero MT, Cabañas R, Contreras J, Martin-Barroso JA, Barranco P, López-Serrano MC. Allergic reactions to Anisakis simplex parasitizing seafood. Ann Allergy Asthma Immunol. 1997;79:246-50.

86. López-Serrano MC, Gomez AA, Daschner A, Moreno-Ancillo A, de Parga JM, Caballero MT, Barranco P, Cabañas R. Gastroallergic anisakiasis: findings in 22 patients. J Gastroenterol Hepatol. 2000;15:503-6.

87. Audicana MT, Ansotegui IJ, de Corres LF, Kennedy MW. Anisakis simplex: dangerous_-dead and alive? Trends Parasitol. 2002;18:20-4

88. Daschner A, Pascual CY. Anisakis simplex: sensitization and clinical allergy. Curr Opin Allergy Clin Immunol. 2005;5:281-5.

89. Choi SJ, Lee JC, Kim MJ, Hur GY, Shin SY, Park HS. The clinical characteristics of Anisakis allergy in Korea. Korean J Intern Med. 2009;24:160-3.

90. Carballeda-Sangiao N, Rodríguez-Mahillo Al, Careche M, Navas A, Moneo I, González-Muñoz M. Changes over time in lgE sensitization to allergens of the fish parasite Anisakis spp. PLoS Negl Trop Dis. 2016;10:e0004864

91. Strøm SB, Haarder S, Korbut R, Mejer H, Thamsborg SM, Kania PW, Buchmann K. Third stage nematode larvae of Contracaecum osculatum from Baltic cod (Gadus morhua) elicit eosinophilic granulomatous reactions when penetrating the stomach mucosa of pigs. Parasitol Res. 2015;114:1217-20.

92. Messina CM, Pizzo F, Santulli A, Bušelić I, Boban M, Orhanović S, Mladineo I. Anisakis pegreffii (Nematoda: Anisakidae) products modulate oxidative stress and apoptosis-related biomarkers in human cell lines. Parasites Vectors. 2016:9:607

93. Acha P, Szyfres B. Zoonoses and communicable diseases common to man and animals. Vol. 3: Parasitoses. 3rd ed. Washington, DC: Pan American Health Organisation; 2003. p. 231-6.

94. Repiso OA, Alcántara TM, González FC, Artaza VT, Rodríguez MR, Valle MJ, Martínez PJL. Gastrointestinal anisakiasis. Study of a series of 25 patients. Gastroenterol Hepatol. 2003;26:341-6 (in spanish).

95. Montalto M, Miele L, Marcheggiano A, Santoro L, Curigliano V, Vastola M, Gasbarrini G. Anisakis infestation: a case of acute abdomen mimicking Crohn's disease and eosinophilic gastroenteritis. Dig Liver Dis. 2005;37:62-4.

96. Tsukui M, Morimoto N, Kurata H, Sunada F. Asymptomatic anisakiasis of the colon incidentally diagnosed and treated during colonoscopy by retroflexion in the ascending colon. J Rural Med. 2016;11:73-5.

97. Caramello P, Vitali A, Canta F, Caldana A, Santi F, Caputo A, Lipani F, Balbiano R. Intestinal localization of anisakiasis manifested as acute abdomen. Clin Microbiol Infect. 2003:9:734-7.

98. Matsumoto T, lida M, Kimura Y, Tanaka K, Kitada T, Fujishima M. Anisakiasis of the colon: radiologic and endoscopic features in six patients. Radiology. 1992;183:97-9.

99. Ido K, Yuasa H, Ide M, Kimura K, Toshimitsu K, Suzuki T. Sonographic diagnosis of small intestinal anisakiasis. J Clin Ultrasound. 1998;26:125-30.

100. Toyoda H, Tanaka K. Intestinal anisakiasis treated successfully with prednisolone and olopatadine hydrochloride. Case Rep Gastroenterol. 2016;10:30-5.

101. Balows A, Hausler WJ Jr, Ohashi M, Turano A. Laboratory diagnosis of infectious diseases: principles and practice. Vol. 1. Bacterial, mycotic, and parasitic diseases. Berlin: Springer; 1988.

102. Ko RC. Fish-borne parasitic zoonoses. In: Woo PTK, editor. Fish diseases and disorders. Vol. 1: Protozoan and metazoan infections. Chapt. 16. Wallingford, Oxfordshire, England: CABI; 2006. p. 611-615.

103. García M, Moneo I, Audicana MT, del Pozo MD, Muñoz D, Fernández E, Díez J, Etxenagusia MA, Ansotegui IJ, de Corres LF. The use of IgE immunoblotting as a diagnostic tool in Anisakis simplex allergy. J Allergy Clin Immunol. 1997;99:497-501.

104. Rodero M, Cuellar C, Chivato T, Mateos JM, Laguna R. Western blot antibody determination in sera from patients diagnosed with Anisakis sensitization with different antigenic fractions of Anisakis simplex purified by affinity chromatography. J Helminthol. 2007:81:307-10.
105. Mattiucci S, Fazii P, De Rosa A, Paoletti M, Megna AS, Glielmo A, De Angelis M, Costa A, Meucci C, Calvaruso V, Sorrentini I, Palma G, Bruschi F, Nascetti G. Anisakiasis and gastroallergic reactions associated with Anisakis pegreffii infection, Italy. Emerg Infect Dis. 2013;19:496-9.

106. Iglesias R, Leiro J, Ubeiro FM, Santamarina MT, Navarrete I, Sanmartin ML. Antigenic cross-reactivity in mice between third-stage larvae of Anisakis simplex and other nematodes. Parasitol Res. 1996;82:378-81.

107. Perteguer MJ, Chivato T, Montoro A, Cuellar C, Mateos JM, Laguna R. Specific and total IgE in patients with recurrent, acute urticarial caused by Anisakis simplex. Ann Trop Med Parasitol. 2000;94:259-68.

108. Hochberg NS, Hamer DH. Anisakidosis: perils of the deep. Clin Infect Dis. 2010;51:806-12.

109. Daschner A, Vega de La Osada F, González Leza B. Specific lgG and IgG4 in patients with lgE-antibodies against Anisakis simplex: acute urticaria in gastro-allergic anisakiasis versus chronic urticarial. J Allegy Clin Immunol. 2002;109:126.

110. Gónzalez-Muñoz M, Luque R, Nauwelaers F, Moneo I. Detection of Anisakis simplex-induced basophil activation by flow cytometry. Cytom B Clin Cytom. 2005;68:31-6.

111. Bernardini R, Lombardi E, Novembre E, Ingargiola A, Pucci N, Favilli T, Vierucci A. Predictors of Anisakis simplex symptoms. Allergy. 2000;55:979-80.

112. García Ara MC, Alonso Gómez A, Martín Muñoz MF, Díaz Pena JM, Daschner A, Ojeda JA. Anisakis simplex (AS) sensitization in children: frequency study. Allergy. 1997;2:67.

113. Weiler CR. Anisakis simplex and cross-reacting antigens. Int J Dermatol. 2007:46:224-5.

114. Valls A, Pascual CY, Martín Esteban M. Anisakis allergy: an update. Rev Fr Allergol. 2005;45:108-13.

115. Caballero ML, Umpierrez A, Perez-Piñar T, Moneo I, de Burgos C, Asturias JA, Rodríguez-Pérez R. Anisakis simplex recombinant allergens increase diagnosis specificity preserving high sensitivity. Int Arch Allergy Immunol. 2012;158:232-40.

116. Caballero ML, Asero R, Antonicelli L, Kamberi E, Colangelo C, Fazii P, de Burgos C, Rodriguez-Perez R. Anisakis allergy component-resolved diagnosis: clinical and immunologic differences between patients from Italy and Spain. Int Arch Allergy Immunol. 2013;162:39-44.

117. Kobayashi Y, Ishizaki S, Shimakura K, Nagashima Y, Shiomi K. Molecular cloning and expression of two new allergens from Anisakis simplex. Parasitol Res. 2007;100:1233-41.

118. López I, Pardo MA. A phage display system for the identification of novel Anisakis simplex antigens. J Immunol Methods. 2011;373:247-51.

119. Anadón AM, Rodríguez E, Gárate MT, Cuéllar C, Romarís F, Chivato T, Rodero M, González-Díaz H, Ubeira FM. Diagnosing human anisakiasis: recombinant Ani s 1 and Ani s 7 allergens versus the UniCAP 100 fluorescence enzyme immunoassay. Clin Vaccine Immunol. 2010;17:496-502.

120. Cuéllar C, Daschner A, Valls A, De Frutos C, Fernández-Fígares V, Anadón AM, Rodríguez E, Gárate T, Rodero M, Ubeira FM. Ani s 1 and Ani s 7 recombinant allergens are able to differentiate distinct Anisakis simplex-associated allergic clinical disorders. Arch Dermatol Res. 2012;304:283-8.

121. Rodríguez E, Anadón AM, García-Bodas E, Romarís F, Iglesias R, Gárate T, Ubeira FM. Novel sequences and epitopes of diagnostic value derived from the Anisakis simplex Ani s 7 major allergen. Allergy. 2008;63:219-25.

122. Lin AH, Nepstad I, Florvaag E, Egaas E, Van Do T. An extended study of seroprevalence of anti-Anisakis simplex IgE antibodies in Norwegian blood donors. Scand J Immunol. 2014;79:61-7.

123. Gamboa PM, Asturias J, Martínez R, Antépara I, Jáuregui I, Urrutia I, Fernández J, Sanz ML. Diagnostic utility of components in allergy to Anisakis simplex. J Investig Allergol Clin Immunol. 2012;22:13-9.

124. Rodriguez-Mahillo Al, Gonzalez-Muñoz M, Gomez-Aguado F, Rodriguez-Perez R, Corcuera MT, Caballero ML, Moneo I. Cloning and characterisation of the Anisakis simplex allergen Ani s 4 as a cysteineprotease inhibitor. Int J Parasitol. 2007;37:907-17.

125. Ibarrola I, Arilla MC, Herrero MD, Esteban MI, Martínez A, Asturias JA. Expression of a recombinant protein immunochemically equivalent to the major Anisakis simplex allergen Ani s 1. J Investig Allergol Clin Immunol. 2008;18:78-83. 
126. Asturias JA, Eraso E, Martínez A. Cloning and high level expression in Escherichia coli of an Anisakis simplex tropomyosin isoform. Mol Biochem Parasitol. 2000;108:263-7.

127. Moore DAJ, Girdwood RWA, Chiodini PL. Treatment of anisakiasis with albendazole. Lancet. 2002;360:54.

128. Pacios E, Arias-Diaz J, Zuloaga J, Gonzalez-Armengol J, Villarroel P, Balibrea JL. Albendazole for the treatment of anisakiasis ileus. Clin Infect Dis. 2005;41:1825-6.

129. Li SW, Shiao SH, Weng SC, Liu TH, Su KE, Chen CC. A case of human infection with Anisakis simplex in Taiwan. Gastrointest Endosc. 2015;82:757-8.

130. Ramos L, Alonso C, Guilarte M, Vilaseca J, Santos J, Malagelada JR. Anisakis simplex-induced small bowel obstruction after fish ingestion: preliminary evidence for response to parenteral corticosteroids. Clin Gastroenterol Hepatol. 2005;3:667-71.

131. Hierro I, Valero A, Pérez P, González P, Cabo MM, Montilla MP, Navarro MC. Action of different monoterpenic compounds against Anisakis simplex s.I. L3 larvae. Phytomedicine. 2004;11:77-82.

132. Gómez-Rincón C, Langa E, Murillo P, Valero MS, Berzosa C, López V. Activity of tea tree (Melaleuca alternifolia) essential oil against L3 larvae of Anisakis simplex. Biomed Res Int. 2014;2014:549510.

133. da Silva Justino $\mathrm{CH}$, Barros LA. In vitro evaluation of the resistence of the Contracaecum sp. larvae (Railliet \& Henry, 1912) (Nematoda: Anisakidae), to the essential oil of citronella (Cymbopogon sp.) (Poaceae). R bras Ci Vet. 2008;15:122-5.

134. Barros LA, Yamanaka AR, Silva LE, Vanzeler MLA, Braum DT, Bonaldo J. In vitro larvicidal activity of geraniol and citronellal against Contracaecum sp. (Nematoda: Anisakidae). Braz J Med Biol Res. 2009;42:918-20.

135. Hierro I, Valero A, Navarro MC. In vivo larvicidal activity of monoterpenic derivatives from aromatic plants against L3 larvae of Anisakis simplex s. I. Phytomedicine. 2006;13:527-31.

136. Romero Mdel C, Valero A, Martín-Sánchez J, Navarro-Moll MC. Activity of Matricaria chamomilla essential oil against anisakiasis. Phytomedicine. 2012;19:520-3

137. Maizels RM, Tetteh KK, Loukas A. Toxocara canis: genes expressed by the arrested infective larval stage of a parasitic nematode. Int J Parasitol. 2000;30:495-508.

138. Jex AR, Liu S, Li B, Young ND, Hall RS, Li Y, et al. Ascaris suum draft genome. Nature. 2011;479:529-33.

139. Itami DM, Oshiro TM, Araujo CA, Periniz A, Martinsz MA, Macedow MS Macedo-Soares MF. Modulation of murine experimental asthma by Ascaris suum components. Clin Exp Allergy. 2005;35:873-9.

140. Oshiro TM, Macedo MS, Macedo-Soares MF. Anti-inflammatory activity of PAS-1, a protein component of Ascaris suum. Inflamm Res. 2005;54:17-21.

141. Antunes MF, Titz TO, Batista IF, Marques-Porto R, Oliveira CF, Alves de Araujo CA, Macedo-Soares MF. Immunosuppressive PAS-1 is an excretory/secretory protein released by larval and adult worms of the ascarid nematode Ascaris suum. J Helminthol. 2015;89:367-74.

142. Araújo CA, Perini A, Martins MA, Macedo MS, Macedo-Soares MF. PAS-1, a protein from Ascaris suum, modulates allergic inflammation via IL-10 and IFN- $\gamma$, but not IL-12. Cytokine. 2008;44:335-41.

143. Araújo CAA, Perini A, Martins MA, Macedo MS, Macedo-Soares MF. PAS-1, an Ascaris suum protein, modulates allergic airway inflammation via $\mathrm{CD}^{+}{ }^{+} \gamma \delta \mathrm{TCR}{ }^{+}$and $\mathrm{CD} 4^{+} \mathrm{CD}_{25}{ }^{+} \mathrm{FoxP}^{+} \mathrm{T}$ cells. Scand J Immunol. 2010;72:491-503.

144. La Rotta A, Higaki Y, Marcos G, Kilimajer J, Zubeldia JM, Baeza ML. Anisakis simplex and Ascaris lumbricoides inhibit the allergic response to peanut in a murine model of anaphylaxis. J Allergy Clin Immunol. 2010;125:AB28.

145. Haarder S, Kania PW, Holm TL, Jørgensen LvG, Buchmann K. Effect of ESproducts from Anisakis (Nematoda: Anisakidae) on experimentally induced colitis in adult zebrafish. Parasite Immunol. 2016 (unpublished data)

146. Buchmann K, Kania P. Emerging Pseudoterranova decipiens (Krabbe, 1878) problems in Baltic cod, Gadus morhua L., associated with grey seal colonization of spawning grounds. J Fish Dis. 2012;35:861-6.

147. Nadolna K, Podolska M. Anisakid larvae in the liver of cod (Gadus morhua) L. from the Southern Baltic Sea. J Helminthol. 2014;88:237-46.

148. Valiñas B, Lorenzo S, Eiras A, Figueiras A, Sanmartín ML, Ubeira FM. Prevalence of and risk factors for lgE sensitization to Anisakis simplex in a Spanish population. Allergy. 2001;56:667-71.
149. Adroher FJ, Valero A, Ruiz-Valero J, Iglesias L. Larval anisakids (Nematoda: Ascaridoidea) in horse mackerel (Trachurus trachurus) from the fish market in Granada, Spain. Parasitol Res. 1996:82:319-22.

150. Del Rey Moreno A, Valero A, Mayorga C, Gómez B, Torres MJ, Hernández J, Ortiz M, Lozano Maldonado J. Sensitization to Anisakis simplex s.l. in a healthy population. Acta Trop. 2006;97:265-9.

151. Puente P, Anadón A, Rodero M, Romarís F, Ubeira F, Cuéllar C. Anisakis simplex: the high prevalence in Madrid (Spain) and its relation with fish consumption. Exp Parasitol. 2008;118:271-4.

152. Rello FJ, Valero A, Adroher FJ. Anisakid parasites of the pouting (Trisopterus luscus) from the Cantabrian Sea coast, Bay of Biscay, Spain. J Helminthol. 2008;82:287-91.

153. Pulleiro-Potel L, Barcala E, Mayo-Hernández E, Muñoz P. Survey of anisakids in commercial teleosts from the western Mediterranean Sea: infection rates and possible effects of environmental and ecological factors. Food Control. 2015:55:12-7.

154. López-Vélez R, García A, Barros C, Manzarbeitia F, Oñate JM. Anisakiasis in Spain. Report of 3 cases. Enferm Infecc Microbiol Clin. 1992;10:158-61.

155. Pampiglione S, Rivasi F, Criscuolo M, De Benedittis A, Gentile A, Russo S, Testini M, Villan M. Human anisakiasis in Italy: a report of eleven new cases. Pathol Res Pract. 2002;198:429-34.

156. Cavallero S, Scribano D, D'Amelio S. First case report of invasive pseudoterranoviasis in Italy. Parasitol Int. 2016;65:488-90.

157. Levsen A, Lunestad BT. Anisakis simplex third stage larvae in Norwegian spring spawning herring (Clupea harengus L.), with emphasis on larval distribution in the flesh. Vet Parasitol. 2010;171:247-53.

158. Karpiej K, Dzido J, Rokicki J, Kijewska A. Anisakid nematodes of Greenland halibut Reinhardtius hippoglossoides from the Barents Sea. J Parasitol. 2013;99:650-4

159. Levsen A, Karl H. Anisakis simplex (s.l.) in Grey gurnard (Eutrigla gurnardus) from the North Sea: food safety considerations in relation to fishing ground and distribution in the flesh. Food Control. 2014;36:15-9.

160. Andreassen J, Jörring K. Anisakiasis in Denmark. Infection with nematode larvae from marine fish. Nord Med. 1970;84:1492-5 (in Danish).

161. Mehrdana F, Bahlool QZ, Skov J, Marana MH, Sindberg D, Mundeling M, Overgaard BC, Korbut R, Strøm SB, Kania PW, Buchmann K. Occurrence of zoonotic nematodes Pseudoterranova decipiens, Contracaecum osculatum and Anisakis simplex in cod (Gadus morhua) from the Baltic Sea. Vet Parasitol. 2014;205:581-7.

162. Haarder S, Kania PW, Galatius A, Buchmann K. Increased Contracaecum osculatum infection in Baltic cod (Gadus morhua) livers (1982-2012) associated with increasing grey seal (Halichoerus gryphus) populations. J Wildl Dis. 2014;50:537-43.

163. Lunneryd SG, Boström MK, Aspholm PE. Sealworm (Pseudoterranova decipiens) infection in grey seals (Halichoerus grypus), cod (Gadus morhua) and shorthorn sculpin (Myoxocephalus scorpius) in the Baltic Sea. Parasitol Res. 2015;114:257-64.

164. Möller H, Schröder S. Neue aspekte der anisakiasis in Deutschland (New aspects of anisakidosis in Germany). Arch Lebensmittelhyg. 1987;38:123-8 (in German)

165. van Thiel P, Kuipers FC, Roskam RT. A nematode parasitic to herring, causing acute abdominal syndromes in man. Trop Geogr Med. 1960:12:97-113.

166. Mladineo I, Poljak V, Martínez-Sernández V, Ubeira FM. Anti-Anisakis IgE seroprevalence in the healthy Croatian coastal population and associated risk factors. PLoS Negl Trop Dis. 2014;8:e2673.

167. Marques JF, Cabral HN, Busi M, D'Amelio S. Molecular identification of Anisakis species from Pleuronectiformes off the Portuguese coast. J Helminthol. 2006;80:47-51.

168. Bourree P, Paugam A, Petithory JC. Anisakidosis: report of 25 cases and review of the literature. Comp Immunol Microbiol Infect Dis. 1995:18:75-84.

169. Umehara A, Kawakami Y, Araki J, Uchida A. Molecular identification of the etiological agent of the human anisakiasis in Japan. Parasitol Int. 2007;56:211-5.

170. Umehara A, Kawakami Y, Ooi HK, Uchida A, Ohmae H, Sugiyama H. Molecular identification of Anisakis type I larvae isolated from hairtail fish off the coasts of Taiwan and Japan. Int J Food Microbiol. 2010;143:161-5. 
171. Quiazon KM, Yoshinaga T, Ogawa K. Distribution of Anisakis species larvae from fishes of the Japanese waters. Parasitol Int. 2011;60:223-6.

172. Im Kl, Shin H, Kim B, Moon S. Gastric anisakiasis in Cheju-do, Korea. Korean J Parasitol. 1995:33:179-86.

173. Na HK, Seo M, Chai JY, Lee EK, Jeon SM. A Case of anisakidosis caused by Pseudoterranova decipiens larva. Korean J Parasitol. 2013;51:115-7.

174. McClelland G, Martell DJ. Surveys of larval sealworm (Pseudoterranova decipiens) infection in various fish species sampled from Nova Scotian waters between 1988 and 1996, with an assessment of examination procedures. NAMMCO Sci Publ. 2001;3:57-76.

175. Couture C, Measures L, Gagnon J, Desbiens C. Human intestinal anisakiosis due to consumption of raw salmon. Am J Surg Pathol. 2003;27:1167-72.

176. Pinkus GS, Coolidge C, Little MD. Intestinal anisakiasis. First case report from North America. Am J Med. 1975;59:114-20.

177. Amin OM, Eidelman WS, Domke W, Bailey J, Pfeifer G. An unusual case of anisakiasis in California, USA. Comp Parasitol. 2000;67:71-5.

178. Bergmann GT, Motta PJ. Infection by anisakid nematodes Contracaecum spp. in the Mayan cichlid fish Cichlasoma (Nandopsis) urophthalmus (Günther 1832). J Parasitol. 2004;90:405-7.

179. Figueiredo Junior I, Vericimo MA, Cardoso LR, São Clemente SC, do Nascimento ER, Teixeira GA. Cross-sectional study of serum reactivity to Anisakis simplex in healthy adults in Niterói, Brazil. Acta Parasitol. 2013:58:399-404
180. Luque JL, Poulin R. Use of fish as intermediate hosts by helminth parasites: a comparative analysis. Acta Parasitol. 2004;49:353-61.

181. Eiras JC, Pavanelli GC, Takemoto RM, Yamaguchi MU, Karkling LC, Nawa Y. Potential risk of fish-borne nematode infections in humans in Brazilcurrent status based on a literature review. FAWPAR. 2016;5:1-6.

182. Torres P, Moya R, Lamilla J. Nematodos anisákidos de interés en salud pública en peces comercializados en Valdivia, Chile. Arch Med Vet. 2000;32:107-13.

183. Mercado R, Torres P, Munoz V, Apt W. Human infection by Pseudoterranova decipiens in Chile: report of seven cases. Mem Inst Oswald Cruz. 2001;96:653-5.

184. Garbin LE, Mattiucci S, Paoletti M, Diaz Jl, Nascetti G, Navone GT. Molecular identification and larval morphological description of Contracaecum pelagicum (Nematoda: Anisakidae) from the anchovy Engraulis anchoita (Engraulidae) and fish-eating birds from the Argentine North Patagonian Sea. Parasitol Int. 2013;62:309-19.

185. Jabbar A, Fong RW, Kok KX, Lopata AL, Gasser RB, Beveridge I. Molecular characterization of anisakid nematode larvae from 13 species of fish from Western Australia. Int J Food Microbiol. 2013;161:247-53.

\section{Submit your next manuscript to BioMed Central and we will help you at every step:}

- We accept pre-submission inquiries

- Our selector tool helps you to find the most relevant journal

- We provide round the clock customer support

- Convenient online submission

- Thorough peer review

- Inclusion in PubMed and all major indexing services

- Maximum visibility for your research

Submit your manuscript at www.biomedcentral.com/submit 